\title{
THE NEEDS FOR SEPTAGE TREATMENT PLANT IN THE URBAN AREAS OF BLITAR REGENCY: A RESEARCH STUDY
}

\author{
Yeni Pratiwi | Ipung Fitri Purwanti* | Joni Hermana
}

Department of Environmental Engineering, Institut Teknologi Sepuluh Nopember,

Surabaya, Indonesia

\section{Correspondence}

*Ipung Fitri Purwanti, Department of Environmental Engineering, Institut Teknologi Sepuluh Nopember, Surabaya, Indonesia. Email: purwanti@enviro.its.ac.id

\section{Present Address}

Gedung Teknik Lingkungan, Kampus ITS Sukolilo, Surabaya 60111, Indonesia

\begin{abstract}
Blitar is one of the regencies in Indonesia that doesn't have Septage Treatment Plant (STP). The high coverage of on-site wastewater system access as well as routine desludging needs in the Decentralized Wastewater Treatment Plant (DWWTP) requires further septage process of septage in the form of STP. However, almost $90 \%$ of STP in Indonesia was not working correctly due to poor effluent quality and inadequate operational and maintenance costs. This study referred to the current conditions of domestic wastewater management obtained from interviews and questionnaires to identify the real needs of establishing STP efficiently and sustainably. Furthermore, this paper contained the analysis of STP capacity, site selection, sludge treatment units, land requirements, capital costs, operational and maintenance costs. By considering the existing desludging activity, the capacity of STP in 2019 was $20.95 \mathrm{~m} 3 /$ day. Meanwhile, the capacity of STP at the end of the 20-year design period was $41.36 \mathrm{~m} 3 /$ day. Although site selection analysis was obtained three locations for STP, the selected location of STP was the one which was centrally located in one location, namely Sutojayan Sub-District. One location of STP was considered to be more efficient from land needs, capital cost, operational and maintenance costs. The total land requirement of the STP was $2,196.49 \mathrm{~m} 2$. The capital cost amounted to IDR 15,562,028,000. The operational and maintenance costs were IDR 319,715/day, while the underlying service tariff charged to the community was IDR $188,000 /$ septic tank.
\end{abstract}

\section{KEYWORDS:}

Capacity, Capital Cost, Efficiency, Land Requirement, Operational and Maintenance Costs 


\section{1 | INTRODUCTION}

The increase in the development of the Septage Treatment Plant (STP) in the regencies and cities is one indicator of Indonesia's Sustainable Development Goals (SDGs) in the wastewater sector. Blitar is one of the regencies that accommodated the STP development plan in the Sanitation Strategy of Blitar Regency (SSK) of the 2016-2020 document. This has also been regulated in the Local Regulation of Blitar Regency Number 5 of 2013 on Blitar Regency Spatial Planning (RTRW) for 2011 - 2031, with urban areas developing the STP service area.

As in 2018, 62.59\% of urban residents in Blitar Regency had access to adequate wastewater. Long-term development plans of wastewater access in urban areas aim to increase the on-site system to $87 \%$. Besides, there are 52 units decentralized wastewater treatment plant (DWWTP) spread across in urban areas which are still operating and require desludging periodically. With the high percentage of access to on-site system wastewater both in the current conditions and development plans and routine desludging needs in the DWWTP, a further process of the existing domestic wastewater treatment systems is needed in the form of STP.

The existing management of septage was by desludging the septage from septic tank and DWWTP. However, the septage was not always disposed of to the nearest STP_-some private desludging services disposed of untreated septage to the river and open fields. The long-distance between the location of STP and the service area causes a high cost to the vehicle fuel. Therefore, to reduce the operational costs, the septage was disposed of carelessly to the nearest waterway and open fields.

Almost 90\% of STPs in Indonesia were not operating correctly due to technical and non-technical factors ${ }^{11}$. One of the technical factors was effluent quality, which has not met the standards for wastewater quality ${ }^{[2]}$. The non-technical factors were inadequate operational and maintenance costs due to the low income caused by the low participation of the public in the desludging septic tank and the lack of Government funding for the STP operation.

Therefore, this study discusses the needs of STP based on real demand surveys as a basis for establishing sustainable and efficient STPs. The study consists of the capacity of the STP in terms of the septage generation rates from septic tanks and DWWTPs, which are used by the community. Furthermore, land and location required by the STP are determined by considering the sludge treatment units used, the efficiency of removing pollutant load, the efficiency of plant area requirements, capital cost, and operational and maintenance costs.

\section{2 | MATERIAL AND METHOD}

The methods used in this study were observation, data comparison, and calculation. The data were obtained through surveys. The study phase included data collection and data analysis.

\section{1 | Data Collection}

Based on the type of data needed, data collection was divided into secondary data and primary data. The secondary data was obtained from Local Government Agencies and documents (i.e., Statistic of Blitar Regency, Health Agency, Housing and Settlement Agency). Secondary data in this study included population information, the numbers of an adequate septic tank, and DWWTP information.

The primary data was obtained from observation through interviews and questionnaires. Questionnaires were given to households that were assumed to use appropriate septic tanks and DWWTP operators. The primary data was also obtained through the results of laboratory sampling and analysis. This study's primary data included latrine ownership and wastewater disposal, condition of blackwater treatment unit and draining frequency; respondents' socio-economic condition; public awareness and willingness to pay septage desludging; and septage characteristics from the nearest STP influent.

\section{2 | Data Analysis}

The data analysis was carried out in 5 steps. The steps were analysis of STP capacity, site selection, treatment units, land requirements, capital cost, and operational and maintenance costs. STP's capacity was determined based on the number of residents in the service area, septage generation rates, and services coverage ${ }^{3}$. The development plan for the STP service area 
was located in urban areas ${ }^{[4]}$. Those areas included the sub-district of Garum, Kanigoro, Kesamben, Ponggok, Sanankulon, Selopuro, Selorejo, Srengat, Sutojayan, Talun, Udanawu, Wlingi, and Wonodadi.

The calculation of STP capacity was done in the next 20 years period $(2019-2038)$. The septage generation rates used were following the current conditions obtained from interviews and questionnaires, namely $0.30 \mathrm{~L} / \mathrm{cap} / \mathrm{day}$ from septic tank users and $0.36 \mathrm{~L} / \mathrm{cap} / \mathrm{day}$ from DWWTP. The value of septage generation rates in this study is still following the Regulation of Minister of Public Works and Housing No. 4 the Year of 2017 on septage generation rates criteria, which is $0.25 \mathrm{~L} / \mathrm{cap} / \mathrm{day}-0.50 \mathrm{~L} / \mathrm{cap} / \mathrm{day}$. The coverage of septic tank services at the beginning of planning referred to the minimum approach from Regulation of Minister of Public Works and Housing No. 4 the Year of 2017 (60\%). Meanwhile, DWWTP services coverage was based on the current condition, which is $1.38 \%$. The population in the service area for 2019-2038 was the result of calculating population projections with a fixed annual population growth rate of $0.45 \%$. The equation of STP capacity calculation is shown Equation 1.

$$
V=\operatorname{deg} \text { service } \times P x \widetilde{Q}
$$

Where $V$ is the capacity of STP (m3/day), $P$ is the population in the service area (capital), and $\widetilde{Q}$ is the average of septage generation rates (m3/cap/day).

The second data analysis is site selection analysis. The result of calculating the STP capacity is one of the considerations for determining the number of STP locations. The mileage to the service area and desludging needs were also considered in determining the location. The scoring method is already following the STP location criteria used to find a suitable site of STP. Alternatives for the location of STP fall into the following eight criteria ${ }^{6}$ : (1) the distance of STP to the service area (weighted score:8; maximum score:88); (2) topography (weighted score:7; maximum score:63); (3) haul time from the service area to STP (weighted score:6; maximum score:42); (4) land use (score:5; maximum score:45); (5) the distance of STP to the nearest waterway (weighted score:4; maximum score:44); (6) land legality (weighted score:3; maximum score:30); (7) administrative boundaries (weighted score:2; maximum score:20); and (8) soil type (weighted score:1; maximum score: 10).

The third data analysis is sludge treatment units and plant area analysis. The sludge treatment units were determined according to the septage characteristics from laboratory test results. It also gave considerations on each technology's advantages and disadvantages to get effective and efficient treatment with low construction and operational costs, small land requirements, and appropriate effluent quality based on Regulation of Minister of Environment No. 68 the Year of 2016 on quality standards of domestic wastewater effluent. Referring to the selected treatment units, preliminary sizing of the site was calculated by identifying the removal efficiency of organic load and pathogenic bacteria.

The fourth data analysis is capital cost analysis. In this study, the capital cost was calculated by determining construction and land procurement costs. The construction cost of the treatment units depends on the sludge flow rate, which will be processed in each treatment unit. The sludge treatment unit costs were defined according to the comparative study of the construction costs in each similar processing unit from existing STP in several cities ${ }^{[7}$. The cost of each treatment unit considered the average inflation factor from Bank Indonesia in 2018 (3.20\%) and the basic unit price (HSPK) in East Java Province in 2018.

The construction cost of STP supporting facilities was $10 \%$ of the construction of treatment unit costs. The supporting facilities of STP consist of the drainage system, office, clean water installation, security post, operational road, and warehouse. The previous report strongly influenced the result of capital cost analysis.

The last data analysis is the operational and maintenance (O\&M) costs analysis. The O\&M costs of STP consist of sludge treatment operating and management costs. This was effected by how the sludge flowrate was treated. O\&M costs were used to determine the basic tariff of desludging services. In addition to considering O\&M costs, the basic fare was influenced by septage transporting fees, hauler truck maintenance costs, number of customers, and desludging periods ${ }^{6}$. Basic tariff calculation uses Equation 2.

$$
\text { basic tariff }=\frac{\text { total } \text { O\&M costs }}{\text { number of customers }}
$$


TABLE 1 The result of STP capacity calculation.

\begin{tabular}{ccccccc}
\hline \multirow{2}{*}{ No } & \multirow{2}{*}{ Year } & \multicolumn{2}{c}{ \%service } & P-cap & $\begin{array}{c}\text { \% desludging } \\
\text { activity }\end{array}$ & V-m3/day \\
\hline 1 & 2019 & $60.00 \%$ & $1.38 \%$ & 745,113 & $15.20 \%$ & 20.95 \\
2 & 2020 & $61.42 \%$ & $1.99 \%$ & 748,487 & $15.20 \%$ & 21.78 \\
3 & 2021 & $62.84 \%$ & $2.60 \%$ & 751,878 & $15.20 \%$ & 22.62 \\
4 & 2022 & $64.26 \%$ & $3.21 \%$ & 755,283 & $15.20 \%$ & 23.46 \\
5 & 2023 & $65.68 \%$ & $3.83 \%$ & 758,704 & $15.20 \%$ & 24.31 \\
6 & 2024 & $67.11 \%$ & $4.44 \%$ & 762,141 & $15.65 \%$ & 25.92 \\
7 & 2025 & $68.53 \%$ & $5.05 \%$ & 765,593 & $15.65 \%$ & 26.81 \\
8 & 2026 & $69.95 \%$ & $5.66 \%$ & 769,060 & $15.65 \%$ & 27.71 \\
9 & 2027 & $71.37 \%$ & $6.27 \%$ & 772,544 & $15.65 \%$ & 28.62 \\
10 & 2028 & $72.79 \%$ & $6.88 \%$ & 776,043 & $15.65 \%$ & 29.53 \\
11 & 2029 & $74.21 \%$ & $7.50 \%$ & 779,558 & $16.10 \%$ & 31.33 \\
12 & 2030 & $75.63 \%$ & $8.11 \%$ & 783,089 & $16.10 \%$ & 32.29 \\
13 & 2031 & $77.05 \%$ & $8.72 \%$ & 786,636 & $16.10 \%$ & 33.25 \\
14 & 2032 & $78.47 \%$ & $9.33 \%$ & 790,199 & $16.10 \%$ & 34.22 \\
15 & 2033 & $79.89 \%$ & $9.94 \%$ & 793,778 & $16.10 \%$ & 35.21 \\
16 & 2034 & $81.32 \%$ & $10.55 \%$ & 797,373 & $16.55 \%$ & 37.21 \\
17 & 2035 & $82.74 \%$ & $11.17 \%$ & 800,985 & $16.55 \%$ & 38.23 \\
18 & 2036 & $84.16 \%$ & $11.78 \%$ & 804,613 & $16.55 \%$ & 39.27 \\
19 & 2037 & $85.58 \%$ & $12.39 \%$ & 808,257 & $16.55 \%$ & 40.31 \\
20 & 2038 & $87.00 \%$ & $13.00 \%$ & 811,918 & $16.55 \%$ & 41.36 \\
\hline
\end{tabular}

\section{3 | RESULTS AND DISCUSSION}

\section{1 | STP Capacity}

The existing condition of desludging activities in urban areas was added to be one of the considerations to define STP capacity ${ }^{3]}$. The current situation of desludging percentage is $24 \%$, with 9-year of the desludging interval, which exceeds the standard of desludging intervals (2-5 years) ${ }^{[8}$. Meanwhile, the public's awareness and willingness to desludge their septic tank, which was $76 \%$, is put into the desludging plan percentage with a 5-year desludging interval. Therefore, in the next 5-year interval, the plan is expected to increase the percentage of desludging activities. This additional desludging percentage will occur due to an increase of septic tank users, the development of local regulations on domestic wastewater management, and the socialization of septage management, including any triggers to desludge septic tank routinely.

The percentage of service at the end of the design period refers to the local government's long-term achievement targets in developing septic tanks and DWWTPs 9 . Therefore, the increase in the percentage of services for septic tanks and DWWTPs was constant every year (1.42\% for septic tank and $0.61 \%$ for DWWTP). The result of the calculation of projected capacity for STP, which starts from 2019 to 2027, can be seen in Table 1.

Table 1 shows that by considering the desludging activities factor in 2019, the needs of STP capacity in the urban areas of Blitar Regency is $19.30 \mathrm{~m} 3 /$ day. Meanwhile, the capacity of STP at the end of the 20-year design period is $45.48 \mathrm{~m} 3 / \mathrm{day}$. Without desludging activities factor, the capacity of STP in 2019 will be $71.10 \mathrm{~m} 3 /$ day and changes to $249.91 \mathrm{~m} 3 /$ day in 2038 . The significant difference of that results makes desludging activity factor as important consideration in determining the design capacity of an STP. Therefore, it will reduce the occurrence of idle capacity when the next STP is built.

\section{2 | Site Selection}

Based on the results of scoring the criteria for the location of the STP, 3 locations of the STP were required. Each of the locations was divided into three service zones (east zone, central zone, and west zone). Subdistricts with the highest scores as the potential location of STP in each zone were Wlingi Sub-District (eastern zone), Sutojayan Sub-District (central zone), and Wonodadi Sub-District (west zone). The determination of the three STP locations was done by considering the distance factor as criteria with the highest weight value since it affects the transportation cost. Since the Local Government of Blitar Regency does not plan about the STP location, the selected site of STP was in the nearest place from the service area. The distance between the nearest and the farthest of the service area is shown in Figure 1. The scoring result of the site criteria can be seen in Table 2. 


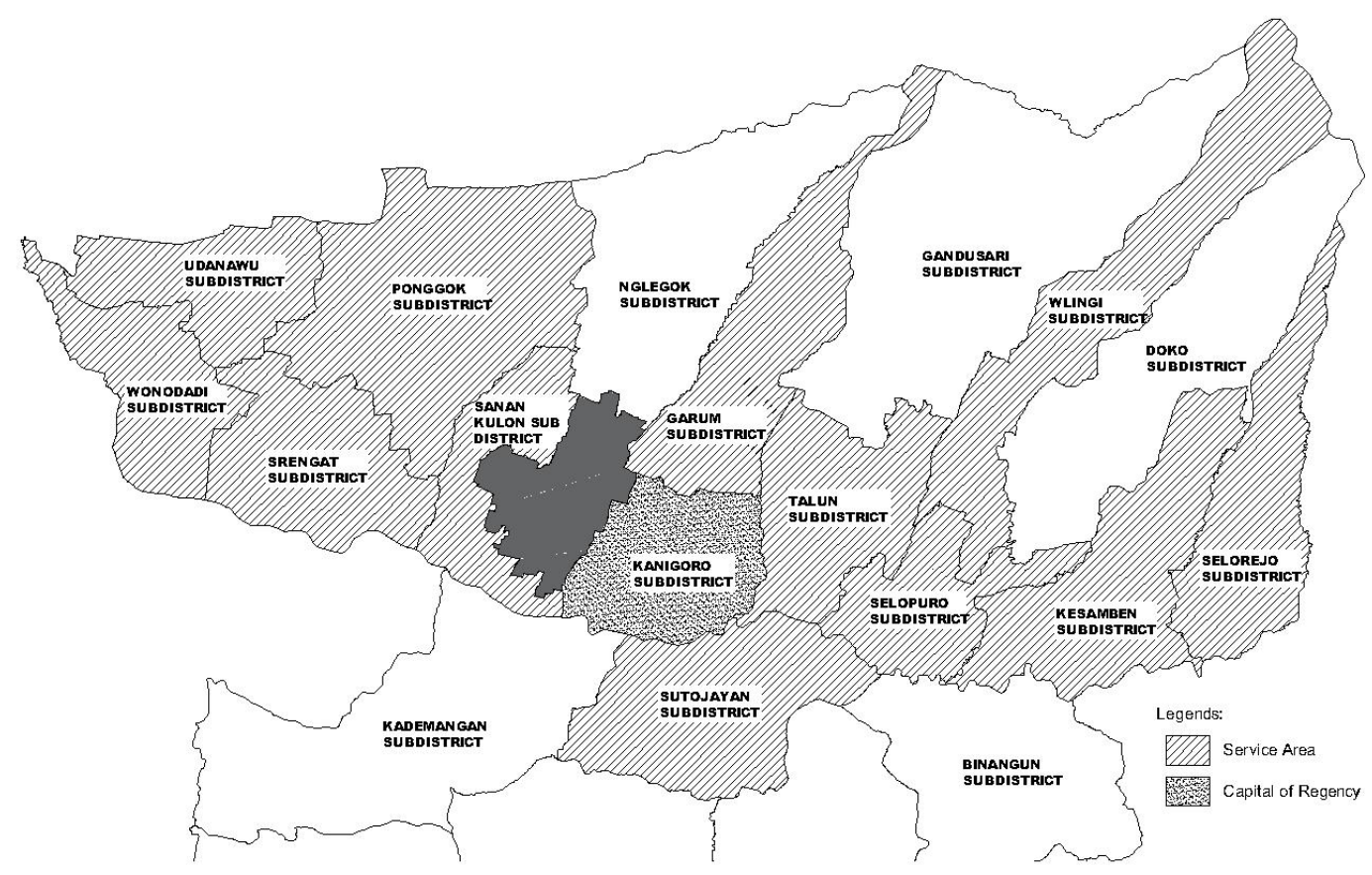

FIGURE 1 The map of the service areas.

Based on the document of the Sanitation Strategy (SSK) of Blitar Regency for 2016 - 2020, the STP development program is only planned for one unit of STP. To manage this condition, the STP location was selected centrally in one location with the highest score, which was Sutojayan Sub-District. To the next analysis, the results of the scoring study, which is following the technical criteria of the STP location with the three locations of the STP, is called Alternative I, while the other with one central location is called Alternative II. These considerations are aimed to find out the most efficient selection alternative.

\section{3 | Requirements of Treatment Units and Plant Area}

The selection of sludge treatment units was depended on some factors such as land necessity; electricity and mechanical needs, which affect the construction and operational and maintenance costs; the possibility of odors; the easiness of operation and maintenance; and the efficiency of organic load and pathogenic bacteria removal. The selection of the treatment units was also looked at by septage characteristics, which is about to be treated. The result of the laboratory test on septage characteristics from the nearest STP influent is shown in Table 3. Meanwhile, Table 4. presents the identification of technologies and factors to determine the treatment units.

According to the consideration of several factors, the chosen treatment unit technologies were Solid Separation Chamber (SSC), Anaerobic Baffled Reactor (ABR), Facultative pond, Maturation pond, and Disinfection with the addition of chlorine. Afterward, the site's preliminary sizing was calculated by identifying the removal efficiency of organic load and pathogenic bacteria 10 [13].

Land requirements for each treatment unit were calculated based on the capacity of STP in 2038 as the end of the design period. The calculation was also based on organic load and pathogenic bacteria in the sludge, which is about to be treated. In Alternative II, where the STP location is centrally in one location, the capacity used was $41.36 \mathrm{~m} 3 /$ day. In the alternative, I, where the STP was located in three different locations, the capacity of each location was determined based on its service area (with $15 \mathrm{~km}$ as the maximum service distance). The following are the capacity for each location in the alternative I: (1) Wlingi Sub-District with service areas in Wlingi, Kesamben, Selorejo, Selopuro, and Talun, which has a capacity of $11.84 \mathrm{~m} 3 /$ day; (2) Sutojayan SubDistrict with service areas in Kanigoro, Talun, Sanankulon, Sutojayan, and Garum, which has a capacity of 13.65 m3/day; and (3) Wonodadi Sub-District with service areas in Udanawu, Wonodadi, Sanankulon, Ponggok, and Srengat which has a capacity of $15.86 \mathrm{~m} 3 /$ day. 
TABLE 2 The result of STP site selection analysis.

\begin{tabular}{|c|c|c|c|c|c|c|c|c|c|c|c|c|c|c|c|}
\hline \multirow{2}{*}{ Criteria } & \multirow{2}{*}{ Sub Criteria } & \multirow{2}{*}{ Score } & \multicolumn{13}{|c|}{ Sub-Districts } \\
\hline & & & 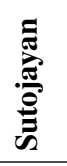 & 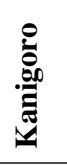 & 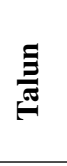 & 总 & 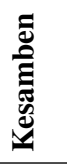 & 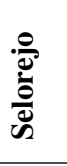 & 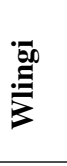 & 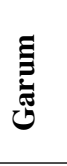 & 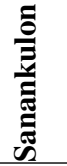 & 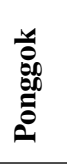 & 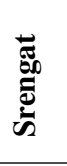 & 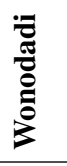 & ह \\
\hline $\begin{array}{l}\text { Distance of } \\
\text { STP to the } \\
\text { service area }\end{array}$ & $\begin{array}{l}>15 \mathrm{~km} \\
10-15 \mathrm{~km} \\
5-10 \mathrm{~km} \\
3-5 \mathrm{~km} \\
<3 \mathrm{~km}\end{array}$ & $\begin{array}{c}3 \\
5 \\
7 \\
9 \\
11\end{array}$ & 56 & 56 & 56 & 56 & 48 & 40 & 56 & 40 & 56 & 40 & 56 & 56 & 56 \\
\hline Topography & $\begin{array}{l}16-25 \% \\
8-15 \% \\
3-7 \%\end{array}$ & $\begin{array}{l}9 \\
7 \\
5\end{array}$ & 49 & 35 & 35 & 35 & 49 & 49 & 49 & 49 & 35 & 35 & 35 & 35 & 35 \\
\hline $\begin{array}{l}\text { Haul time from } \\
\text { the farthest } \\
\text { service area to } \\
\text { STP }\end{array}$ & $\begin{array}{l}>1 \text { hour } \\
45 \mathrm{~min}-1 \text { hour } \\
30 \mathrm{~min}-45 \mathrm{~min} \\
20 \mathrm{~min}-30 \mathrm{~min}\end{array}$ & $\begin{array}{l}1 \\
3 \\
5 \\
7\end{array}$ & 18 & 18 & 18 & 6 & 6 & 6 & 6 & 18 & 6 & 6 & 6 & 6 & 6 \\
\hline $\begin{array}{l}\text { Land use refers } \\
\text { to RTRW }\end{array}$ & $\begin{array}{l}\text { Housing } \\
\text { Industry } \\
\text { Plantation } \\
\text { Agriculture }\end{array}$ & $\begin{array}{l}3 \\
5 \\
7 \\
9\end{array}$ & 45 & 45 & 45 & 45 & 45 & 35 & 35 & 45 & 45 & 15 & 15 & 45 & 45 \\
\hline $\begin{array}{l}\text { Distance of } \\
\text { STP to the } \\
\text { nearest } \\
\text { waterway }\end{array}$ & $\begin{array}{l}>30 \mathrm{~km} \\
20-29 \mathrm{~km} \\
10-19 \mathrm{~km} \\
3-9 \mathrm{~km} \\
<3 \mathrm{~km}\end{array}$ & $\begin{array}{c}3 \\
5 \\
7 \\
9 \\
11\end{array}$ & 44 & 44 & 44 & 44 & 44 & 44 & 44 & 44 & 44 & 36 & 36 & 44 & 44 \\
\hline Land Legality & & & & & & & & & & & & & & & \\
\hline RTRW & $\begin{array}{l}\text { Suitable } \\
\text { Negotiable }\end{array}$ & $\begin{array}{l}10 \\
5\end{array}$ & 30 & 30 & 30 & 15 & 30 & 30 & 30 & 30 & 30 & 30 & 30 & 30 & 15 \\
\hline $\begin{array}{l}\text { Community } \\
\text { Support }\end{array}$ & $\begin{array}{l}\text { Full } \\
\text { supported } \\
\text { Negotiable }\end{array}$ & $\begin{array}{l}10 \\
5\end{array}$ & & & & & & & & & & & & & \\
\hline $\begin{array}{l}\text { Administrative } \\
\text { Boundary }\end{array}$ & $\begin{array}{l}\text { Inside area } \\
\text { Outside area }\end{array}$ & $\begin{array}{c}10 \\
2\end{array}$ & 20 & 20 & 20 & 20 & 20 & 20 & 20 & 20 & 20 & 20 & 20 & 20 & 20 \\
\hline Soil type & $\begin{array}{l}\text { Clay } \\
\text { Silt } \\
\text { Sand }\end{array}$ & $\begin{array}{l}10 \\
5 \\
2\end{array}$ & 10 & 10 & 10 & 10 & 10 & 10 & 10 & 10 & 10 & 10 & 10 & 10 & 10 \\
\hline Total & & & 272 & 258 & 258 & 231 & 244 & 234 & 250 & 256 & 246 & 192 & 208 & 230 & 215 \\
\hline
\end{tabular}

TABLE 3 The result of laboratory test on Septage Characteristics.

\begin{tabular}{cccc}
\hline Parameter & Unit & Value & Method \\
\hline $\mathrm{pH}$ & 7.50 & $\mathrm{pH}$ meter & Winkler \\
$\mathrm{BOD}$ & $\mathrm{mg} / \mathrm{L}$ & 11,170 & Reflux/ Titrimetric \\
COD & $\mathrm{mg} / \mathrm{L}$ & 20,748 & Gravimetric \\
TSS & $\mathrm{mg} / \mathrm{L}$ & 12,530 & Multi-tube Fermentation \\
\hline
\end{tabular}

Table 5 presents the result of area calculation in each treatment unit. For Alternative I, area Wlingi has flowrate of $11.84 \mathrm{~m} 3 /$ day and organic load of $132.30 \mathrm{~kg} /$ day. Area Sutojayan has flowrates of $13.65 \mathrm{~m} 3 / \mathrm{day}$ and organic load of $152.49 \mathrm{~kg} / \mathrm{day}$. Area Wonodadi has flowrates of $15.86 \mathrm{~m} 3 /$ day and organic load of $177.20 \mathrm{~kg} / \mathrm{day}$. For Alternative II, area Sutojayan has flowrates of $41.36 \mathrm{~m} 3 /$ day and organic load of $461.99 \mathrm{~kg} /$ day.

Thus, Table 6 shows the effect of effluent quality and the efficiency of organic load removal. The right-most column is the quality standard of Domestic Wastewater Effluent. Table 6 clearly shows that the effluent quality in each alternative was lower than the standard variety. Meanwhile, Table 5 presents that Alternative I (STP in three locations) required an area of 2,297.52 m2, and Alternative II (STP in one location) required as much as 2,196.49 $\mathrm{m} 2$. Based on the factor of land requirements, these results indicate that to produce effluents below the quality standard, Alternative II is more efficient than Alternative I since less area is required. 
TABLE 4 Alternative technology for sludge treatement plant.

\begin{tabular}{|c|c|c|c|c|c|c|c|}
\hline \multirow{2}{*}{ Technology } & \multirow{2}{*}{ Lad Necessity } & \multirow{2}{*}{$\begin{array}{c}\text { Electrical and } \\
\text { Mechanical Needs }\end{array}$} & \multirow{2}{*}{ Ordors } & \multirow{2}{*}{ O\&M Cost } & \multicolumn{3}{|c|}{ Removal Efficiency } \\
\hline & & & & & TSS & BOD & COD \\
\hline Gravity Thickener & adjustable & low & high & affordable & 92 & 80 & \\
\hline Anaerobic digester & adjustable & medium & high & expensive & $50-75$ & 80 & 75 \\
\hline Imhoff Tank & adjustable & low & low & affordable & $50-70$ & $10-40$ & $25-50$ \\
\hline SSC & large & low & low & affordable & 70 & 50 & 17 \\
\hline Anaerobic ponds & large & low & high & affordable & 80 & 70 & 65 \\
\hline $\mathrm{ABR}$ & adjustable & low & low & affordable & $80-90$ & $70-95$ & $65-90$ \\
\hline UABF & adjustable & low & low & affordable & $50-80$ & $50-80$ & 55 \\
\hline Aeration ponds & adjustable & high & low & expensive & $80-90$ & $95-98$ & $90-95$ \\
\hline Oxidation Ditch & large & high & low & expensive & $80-90$ & $80-95$ & $80-90$ \\
\hline Trickling filter & adjustable & high & high & expensive & $60-70$ & $80-90$ & $60-70$ \\
\hline Facultative ponds & large & low & high & affordable & 85 & $70-90$ & 80 \\
\hline Maturation ponds & large & low & medium & affordable & 80 & 60 & 60 \\
\hline Constructed wetland & adjustable & low & low & affordable & & & \\
\hline Disinfection & adjustable & medium & low & affordable & & & \\
\hline
\end{tabular}

TABLE 5 Land requirements in each location of alternative technology quantity unit.

\begin{tabular}{lcccccc}
\hline Technology & Quantity & Unit & Wligi & $\begin{array}{c}\text { Alternative I } \\
\text { Sutojayan }\end{array}$ & $\begin{array}{c}\text { Wonodadi } \\
\text { Alternative II } \\
\text { Sutojayan }\end{array}$ \\
\hline Solid Separation Chamber (SSC) & 4 & $\mathrm{~m} 2$ & 193.18 & 193.18 & 234.64 & 567.43 \\
Anaerobic Baffled Reactor (ABR) & 1 & $\mathrm{~m} 2$ & 6.70 & 6.40 & 9.30 & 26.30 \\
Sludge Drying Bed & 4 & $\mathrm{~m} 2$ & 50.00 & 54.08 & 72.00 & 162.00 \\
Facultative ponds & 1 & $\mathrm{~m} 2$ & 16.76 & 19.32 & 22.45 & 58.52 \\
Maturation ponds & 3 & $\mathrm{~m} 2$ & 185.02 & 213.25 & 247.81 & 646.08 \\
Chlorine contact tank & 1 & $\mathrm{~m} 2$ & 0.50 & 0.50 & 0.61 & 2.00 \\
Control/inspection box & 4 & $\mathrm{~m} 2$ & 2.00 & 2.00 & 2.00 & 2.00 \\
Total areas of treatment unit & & $\mathrm{m} 2$ & $\mathbf{4 5 4 . 1 6}$ & $\mathbf{4 8 8 . 7 2}$ & $\mathbf{5 8 8 . 8 0}$ & $\mathbf{1 , 4 6 4 . 3 3}$ \\
Areas of STP supporting facilities & & $\mathrm{m} 2$ & 227.08 & 244.36 & 294.40 & 732.16 \\
and landscape & & & & & & $\mathbf{2 8 3}$ \\
Areas of plant & & $\mathrm{m} 2$ & $\mathbf{6 8 1 . 2 3}$ & $\mathbf{7 3 3 . 0 9}$ & $\mathbf{8 8 3 . 2 0}$ & $\mathbf{2 , 1 9 6 . 4 9}$ \\
\hline
\end{tabular}

TABLE 6 Treatment performance in each alternative location under various flowrates.

\begin{tabular}{|c|c|c|c|c|c|c|c|c|c|}
\hline \multirow{2}{*}{ Parameter } & \multicolumn{2}{|c|}{ Wligi } & \multicolumn{2}{|c|}{$\begin{array}{c}\text { Alternative I } \\
\text { Sutojayan }\end{array}$} & \multicolumn{2}{|c|}{ Wonodadi } & \multicolumn{2}{|c|}{$\begin{array}{c}\text { Alternative II } \\
\text { Sutojayan }\end{array}$} & \multirow{2}{*}{$\begin{array}{l}\text { Quality } \\
\text { Standard* }\end{array}$} \\
\hline & Influent & Effluent & Influent & Effluent & Influent & Effluent & Influent & Effluent & \\
\hline Flowrates (m3/day) & 11.84 & 10.43 & 13.65 & 12.02 & 15.86 & 13.97 & 41.36 & 36.43 & \\
\hline Mass Loading & & & & & & & & & \\
\hline BOD (kg/day) & 132.30 & 0.20 & 152.49 & 0.11 & 177.20 & 0.10 & 461.99 & 0.21 & \\
\hline COD (kg/day) & 245.75 & 1.00 & 283.24 & 0.80 & 329.14 & 0.84 & 858.13 & 2.03 & \\
\hline TSS (kg/day) & 148.41 & 0.13 & 171.05 & 0.15 & 198.77 & 0.18 & 518.24 & 0.47 & \\
\hline Quality & & & & & & & & & \\
\hline BOD (mg/l) & 11,170 & 18.80 & 11,170 & 9.24 & 11,170 & 7.15 & 11,170 & 5.72 & 30 \\
\hline COD (mg/l) & 20,748 & 95.63 & 20,748 & 66.38 & 20,748 & 60.00 & 20,748 & 55.64 & 100 \\
\hline $\mathrm{TSS}(\mathrm{mg} / \mathrm{l})$ & 12,530 & 12.80 & 12,530 & 12.80 & 12,530 & 12.80 & 12,530 & 12.80 & 30 \\
\hline Total Coliform & $8 \times 1012$ & 397 & $8 \times 1012$ & 397 & $8 \times 1012$ & 397 & $8 \times 1012$ & 397 & 3000 \\
\hline
\end{tabular}

Source: * Regulation of Minister of Environment No. 68 (2016)

\section{4 | Capital Cost}

Depending on STP's capacity and anticipating the occurrence of significant idle capacity at the beginning of the operation, the construction of the treatment unit was divided into 2 phases. The first phase was developing the STP capacity up to the first ten years $(2019$ - 2028). The second phase was increasing the capacity according to the STP's needs until the end of the design period (2038).

From the results of the comparative study and inflation consideration, the need for capital costs was obtained in both alternatives, and it can be seen in Table 7 .

Table 7 shows that the capital cost in Alternative II was more effective in terms of the budget than Alternative I. The capital cost of alternative I (accumulated from three locations) was IDR 15,602,440,000 and IDR 15,562,028,000 for Alternative II. These 
TABLE 7 The results of capital cost calculation.

\begin{tabular}{|c|c|c|c|c|c|c|c|c|}
\hline \multirow{2}{*}{ Parameter } & \multicolumn{2}{|c|}{ Wligi } & \multicolumn{2}{|c|}{$\begin{array}{l}\text { Alternative I } \\
\text { Sutojayan }\end{array}$} & \multicolumn{2}{|c|}{ Wonodadi } & \multicolumn{2}{|c|}{$\begin{array}{l}\text { Alternative II } \\
\text { Sutojayan }\end{array}$} \\
\hline & 2018 & 2028 & 2018 & 2028 & 2018 & 2028 & 2018 & 2028 \\
\hline & 8.46 & 11.8 & 9.75 & 13.65 & 11.33 & 15.86 & 29.53 & 41. \\
\hline$t$ of treat- & $1,190,488$ & $2,284,670$ & $1,372,140$ & $2,633,280$ & $1,594,493$ & $3,059,997$ & $4,157,120$ & $7,977,948$ \\
\hline st of sup- & 119049 & 8.467 & 37,214 & 263,328 & 159,449 & 306,000 & 415,712 & 797,795 \\
\hline & $1,309,537$ & $2,513,13$ & 1500254 & 2.85 & 1,7 & 3,3 & 4,5 & 8,77 \\
\hline & & & & & & & & \\
\hline $\begin{array}{l}\text { Total of the final construc- } \\
\text { tion costs }\end{array}$ & 1 & 4, & 289 & $3,186,269$ & $1,929,336$ & 3,702, & $5,030,116$ & $9,653,317$ \\
\hline $\begin{array}{l}\text { Land procurement c } \\
\text { Capital cost }\end{array}$ & $\begin{array}{r}272,493 \\
1,712,984\end{array}$ & $2,764,451$ & $\begin{array}{r}293,234 \\
1,953,524\end{array}$ & $3,186,269$ & $2,282,616$ & $3,702,597$ & $\begin{array}{r}878,595 \\
5,908,711\end{array}$ & $9,653,317$ \\
\hline
\end{tabular}

TABLE 8 The basic tariff of desludging service.

\begin{tabular}{llccc}
\hline Cost Factor & Wligi & $\begin{array}{c}\text { Alternative I } \\
\text { Sutojayan }\end{array}$ & Wonodadi & $\begin{array}{c}\text { Alternative II } \\
\text { Sutojayan }\end{array}$ \\
\hline O\&M Costs (IDR/day) & 243,731 & 248,384 & 254,079 & 319,715 \\
Collection Cost (IDR/day) & 427,148 & 439,130 & 480,607 & $1,271,370$ \\
The number of customers & 4,865 & 5,607 & 6,516 & 16,989 \\
Basic tariff & 276,800 & 246,100 & 226,300 & 188,000 \\
\hline
\end{tabular}

imply that judging from the factor of capital cost needs, the selection of alternative II is more efficient. Land requirements affect the amount of land procurement cost, which also affects the needs of capital cost.

\section{5 | O\&M costs}

O\&M costs of STP are costs incurred by the government to operate and maintain the equipment and facilities in the STP site. The funding source for O\&M costs is the Local Government of Blitar Regency. The following are the amount of O\&M costs in each alternative location in the first year of the STP planned to operate (2019):

(1) In Alternative I, the O\&M costs total were IDR 746,193 / day. O\&M costs in each location were IDR 243,731/ day in Wlingi Sub-District, IDR 248,384/ day in Sutojayan Sub-District, and IDR 254,079/ day in Wonodadi Sub-District. (2) In alternative II, the O\&M costs total were IDR 319,715/ day.

The amount of O\&M costs in this study were influenced by the number of households that were served, desludging period, how the sludge flowrates were treated, and operational cost for built assets. From the O\&M costs calculations, there was an indication that the more significant number of STPs (Alternative I) requires higher O\&M costs. Furthermore, the basic tariff of service was calculated based on O\&M cost. Besides that, septage transporting cost and hauler truck maintenance costs were also added. The basic fare is determined as a tariff for a septage desludging once in a specific period. The desludging interval was adjusted to the planning (5-year). The planned profit was $10 \%$ of the basic tariff calculation. The amount of basic tariff for septage service charged to the public is shown in Table 8 . All cost are in thousand rupiahs.

From Table 8, it is known that the overall cost in Alternative II is lower than alternative I. The distance between the service area and the STP in Alternative II is farther than Alternative I. However, the average of tariff on Alternative I (IDR 249,700/ septic tank) is still more expensive than Alternative II (IDR 188,000/ septic tank). This is due to the O\&M costs and fewer numbers of customers (in term of households) in each location in the alternative I, thus affecting the amount of the tariff. However, all of the locations in both alternatives still meet the average of public willingness to pay for septage desludging (IDR 265,000/septic tank), except in Wlingi (IDR 276,800/ septic tank).

Based on these results, it is expected that desludging activity will increase as a form of community participation. Public participation will increase the income of STP to cover O\&M costs. As a result, STPs can operate adequately as planned. The results 
TABLE 9 Comparison of the overall analysis results.

\begin{tabular}{lrrrr}
\hline Parameters & & \multicolumn{2}{c}{ Alternative I } & \multicolumn{2}{c}{ Alternative II } \\
Sutojayan
\end{tabular}

of the calculation of O\&M costs indicated that the selection of Alternative II is more efficient than alternative I. Result comparison of the overall analysis of Alternative I and Alternative II, regarding land requirements, effluent quality, capital cost, O\&M costs, and basic tariff can be seen in Table 9 .

Table 9 shows that Alternative II, where the location of STP was centralized in one location, is more efficient than three locations of STP by observing from several factors such as land requirements, capital cost, and O\&M costs. Also, the basic tariff of the service that would be charged to the public is cheaper in Alternative II. Nevertheless, in term of effluent quality, both alternatives has below quality standard.

\section{4 | CONCLUSION}

Based on the conducted study on the capacity of STP and the criteria of site selection, STP should be located in three locations, which are spread around the service area (Alternative I). However, referring to the Blitar Regency Sanitation Strategy (SSK) document for 2016 - 2020; the efficiency of land requirements; and the efficiency of total costs (capital cost and O\&M costs), STP location which was centrally in one location (Alternative II) turned out to be more efficient. Therefore, it is suggested that the planning and the development of STP in the future refer to conditions of need in Alternative II. The result of Alternative II analysis are as follows.

First, the capacity of STP in 2019 is $20.95 \mathrm{~m} 3 /$ day, while STP capacity at the end of the design period is $41.36 \mathrm{~m} 3 /$ day. Second, STP location, which has the highest score, is Sutojayan Sub-District. Third, required an area of 2,196.49 m2. Fourth, the need for the capital cost is IDR 15,602,440,000. Fifth, operational and maintenance cost in 2019 is IDR 319,715/ day. Finally, the basic tariff of the service charged to the public is IDR 188,000/ septic tank.

The weakness of Alternative II is the distance between several service areas and the STP location, which is still far enough. This has the potential to cause private desludging services to dispose of untreated septage to the nearest waterway and open fields. To manage this, the Local Government should develop regulations and strict legal sanctions on wastewater management and establish a partnership program with private sectors to always transfer septage from septic tanks and DWWTPs into the STP. The results of the study have considered current conditions of wastewater management and development plan in Blitar Regency. Also, the study results have already adjusted to public awareness and willingness to pay septage desludging

\section{References}

1. AECOM International Development, Inc ; Department of Water dan Sanitation in Developing Countries SFIoASdTS. A Rapid Assessment of Septage Management in Asia: Policies and Practices in India, Indonesia, Malaysia, the Philippines, Sri Lanka, Thaildan, dan Vietnam. Thailand: United States Agency for International Development (USAID) Regional Development Mission for Asia (RDMA; 2010.

2. Hidayat H, Sasmita A, Reza M. Septage Treatment Plant Construction Design in Tampan Sub-Distric, Pekanbaru City. Jom FTEKNIK 2017;4(1):1-7.

3. Tayler K, Siregar R, Darmawan B, Blackett I, Gilner S. Development of Urban Septage Management Models in Indonesia. Waterlines 2013;32(3):221-236. 
4. Meidiana C. Development of Waste Management Practices in Indonesia. European Journal of Scientific Research 2010;40(2):199-210.

5. Irawan A, Santoso EB. Analytical Tools Beyond Gini Index to Study Inequality: a Case of City of Blitar, East Java, Indonesia. (IOP) Conference Series: Earth and Environmental Science 2019;340:012004.

6. Kusuma S, Aulia B, Farikha N. Problem Identification of Micro Hydro Power Plant Program in East Java Province. (IOP) Conference Series: Earth and Environmental Science 2019;340.

7. Hansen DR, Moen MM. Management Accounting. 6 ed. United Stated of America: Thomson South Western; 2003.

8. National Standardization Agency, Agency NS, editor, Planning Procedure for Septic Tank with Advanced Processing (Infiltration Wells, Infiltration Fields, Up Flow Filters, Sanita Ponds. National Standardization Agency; 2017. https: //www.scribd.com/document/452472308/SNISNI-2398-translate-Rev01.

9. Blitar Regency Sanitation Working Group, Group BRSW, editor, Sanitation Strategy of Blitar Regency (SSK) of 2016 2020. Government of Blitar Regency; 2015.

10. Tchobanoglou G, Burton F, Metcalf, Eddy. Wastewater Engineering: Treatment, Disposal and Reuse. 3 ed. New York: McGraw-Hill; 1991.

11. Qasim SR. Wastewater Treatment Plants. New York: CBS Publishing Japan Ltd; 1985.

12. Center for Environmental Research Information (U S ). Guide to Septage Treatment and Disposal Guide to Septage Treatment Disposal, vol. EPA/625/R-. Cincinnati, OH : U.S.: Environmental Protection Agency, Office of Research and Development : Office of Science, Planning and Regulatory Evaluation : Center for Environmental Research Information; 1994.

13. Heinss U, Larmie SA, Strauss M. Solid Separation and Pond Systems for The Treatment of Faecal Sludges in Tropics. 2 ed. Duebendorf,Switzerland: SANDEC - Water and Sanitation in Developing Countries; 1998.

How to cite this article: Pratiwi Y., Purwanti I.P., Hermana J., (2020), The Needs for Septage Treatment Plant in The Urban Areas of Blitar Regency: A Research Study, IPTEK The Journal of Technology and Science, 31(2):148-157. 